\title{
The Concept Of Branding In Islamic Business Ethics Perspetive
}

\author{
Lina Herlina ${ }^{1}$, M. Luthfi Hamidi², Muhammad Doddy ${ }^{3}$
}

${ }^{1}$ SEBI: Email: linaherlina1357@gmail.com

${ }^{2}$ SEBI Lecturer \& Doctoral Candidate Grifith University. Email: lutfihamidi26@ gmail.com

${ }^{3}$ SEBI Lecturer \& Doctoral Candidate AeU Malaysia, Email: doddy.abe@gmail.com

\begin{abstract}
The objective of this paper is to find out and illustrate the concept of branding that comply with Islamic law. The research method used in this study is a literature review, with books and journals as the main data sources, while using the view point of the Qur'an, Hadith, Ijtihad of the scholars, and other scientific works that related to the research. This study introduces the concept of branding that comply with sharia law that covers the role of branding in business, i.e.: as a differentiator, as an advertisement and appeal, as an image-building tool and as a market controller. Branding ethics in Islam including positive image, Islamic products, fair prices, Islamic brands and advertisement variables that have been adapted to comply the rules of Islamic muamalah, and various examples of branding practices in Indonesia that is sharia compliant, for example: Rabbani brand, Wardah cosmetics, and Sofyan hotel. In this case, branding practice that comply with Islamic ethics is not just an idealistic theory, but it can realistically be applied on practice and has been proven to yield positive brand image and loyality from their consumers
\end{abstract}

Keywords: Branding, Islamic Branding, Business Ethics, and Branding Cases

\section{INTRODUCTION}

Business is a human economic activity that aims to seek profits or profits that are inseparable from competitive activity. To maintain the existence of its business, management competed to create various strategies to win market competition. One way or strategy to gain consumer loyalty and win the market is by developing a brand or also called branding.

Although branding practices have been going on for centuries, the meaning of brand meaning has undergone a significant evolutionary process. Broadly speaking, the development of brand meanings is grouped into three stages: (1) brand as identity, (2) brand as equity and (3) brand as commodity (Tjiptono, 2014). Without a brand, a product only becomes a commodity that is sold at a much lower price (Dewi et al, 2005).

But in determining this branding strategy each element must be considered, because ethical problems often arise from the variable elements. As an example of a problem that arises from a spokesperson, endorser or advertising star who plays the advertisement of a product, namely the problem of dressing, speaking, acting vulgarly, such as in a famous water pump advertisement (KPI, 2016). In terms of products, there are cases of bread that resemble the sensitive 
54 | Lina Herlina, M.Luthfi Hamidi, Muhammad Doddy: The Concept of Branding in Islamic Business Ethics Perspetive

organs of men who are warned by the Indonesian Broadcasting Commission (Liputan6, 2017). In addition, there are many cases of logo disputes, including the case of a local company selling catfish pecel, whose logo is considered to copy the coffee shop logo from the United States (Merdeka, 2014). Corporate logo dispute cases also occur in small and medium enterprises (SMEs), namely Durian Durio, whose logo is copied by the company Duriorio (M. Arwan Fatimi, personal interview, November 20, 2017). And other cases of branding efforts that cross the boundaries of Islamic ethics.

Prophet Muhammad PBUH has pointed out that Islam is very concerned about "business" (commerce) as a livelihood for its people. However, in trading, Islam has also determined its signs. Sweet words that are full of promising sales in a brand slogan aim to seduce, even anesthetize the community so they want to buy the products offered. The problem is whether all the promises that are packaged in a branding will be realized or not? Are prices that skyrocket a benchmark for branding quality? In the process of branding, can the company justify any means to dominate the market? Not a few companies only sell promises in their brands, regardless of whether the quality of the product being advertised is truly in accordance with their reality or leaving the boundaries of the Shari'a to pursue economic profit.

From the background above, we can know that branding plays an important role in the development of the company. Besides that, branding has an interface with muamalah in Islamic business ethics, so that Islam has its own view of branding. From this background, the author formulated the question: What is the branding ethic that is compatible with Islamic business?

\section{LITERATURE REVIEW}

\section{BRAND}

\section{Definition of Brand}

According to the American Marketing Association (AMA) defines a brand as: "Names, terms, signs, symbols, designs, or combinations thereof, intended to identify goods or services from one seller or group of sellers and differentiate products or services from competitors" (Kotler and Keller, 2009). Whereas brand understanding is further suggested by Kotler and Keller (2009) that the brand's development is not just a name, term, sign, symbol or combination. Moreover, the brand is a 'commitment' of the company that consistently provides features, benefits and services to customers.

Brand element Is a trade name giving tool that identifies and differentiates a brand (Kotler, 2000). The elements of branding include: Brand name, logo, visual appearance, endorsement, tagline and sound or song. These brand elements are commonly used by companies as attributes and media to do branding in order to get a positive brand image in the community, in the hope that they will get consumer loyalty. 
Jurnal Ekonomi dan Perbankan Syariah

Vol. 7. No.1, April 2019: 53-67, ISSN (cet): 2355-1755 | ISSN (online): 2579-

6437

$\mathbf{5 5}$

Brand image is a set of brand associations that are formed and attached to the minds of consumers (Rangkuti, 2004). The factors forming a Brand Image according to Schiffman and Kanuk (2006) are quality and quality, reliable and reliable, usability or benefits, service, price and image.

\section{The Role of Branding in Business}

According to Tjiptono (2014) the function and role of branding in business is a differentiator. A product will have a difference with its competitors if it has a strong brand, so that a brand or trademark can be easily distinguished from other brands.

Besides that, branding also acts as a promotion and attraction. According to Hendrawan (2014), in addition to physical excellence, there are other considerations, this non-physical advantage can be in the form of status attributes and values inherent in a brand that is difficult to trace or hijack by other producers.

Furthermore, the brand also acts as an image builder, trustee, guarantee of quality and prestige. A brand functions to shape the image by giving the community the first recognition tool. Brands can act as fundamental concepts or themes for all business or marketing activities (Hendrawan, 2014).

Finally, brands act as market controllers. A brand will be a warning to competitors to take each step, besides that the community will automatically provide additional information to others with the brand that is remembered by them or known as word of mouth (Oktaviani et al, 2018).

From this explanation it can be understood that a brand is an identity that will produce an image which is then able to become a market controller through consumer loyalty. Brands contained in a sharia entity require and give responsibility for the application of ethical values in every activity carried out.

\section{ETHICS IN ISLAM}

Islam laid the foundation of its truth in the Qur'an. Whereas western philosophy is basically "Intellect". The key to ethical and real business morals lies in the culprit that is why the mission sent by Rasulullah to the world is to improve human morals that have been damaged (Badroen et al., 2006).

Referring to Harahap (2011), some ethical behaviors in business from an institutional point of view include: (1) Keep holding Islamic law and sharia, (2) The economy is not the only goal, must always be balanced with other aspects, (3) (4) Make business activities as part of worship in accordance with the concept of sharia, (5) Do not carry out any form of usury in any form, speculation, gambling (gharar, maysir), and (6) always encourage raising dignity the lives of the poor.

According to Beekun in There are 5 principles (axioms) that underlie Islamic ethics to determine the principles adopted in carrying out their business 
56 | Lina Herlina, M.Luthfi Hamidi, Muhammad Doddy: The Concept of Branding in Islamic Business Ethics Perspetive

(Badroen, et al 2006). The axioms are as follows: unity (the concept of monotheism), equilibium (balance), free will, responsibility.

\section{Ethics of Branding in Islam}

\section{Positive Image: Building Loyalty (Al-Wala' wal Bara')}

Fauzan (1998) explains the word wala 'meaning the need to build closeness with fellow Muslims by loving, helping, helping those from groups who are hostile to them. Whereas bara 'means deciding on interactions with nonMuslim groups, not loving, and supporting their activities. In other words, in the context of products, Wala encourages every Muslim to be more loving and loyal to the products and services offered by fellow Muslims. At the same time leaving or deciding $\left(\mathrm{bara}^{\prime}\right)$ from the loyalty of using products and services produced by non-Muslims as a form of reflection of love for Allah SWT.

From this point it can be concluded that to get a good image in branding that is in accordance with Islamic ethics, loyalty that should be built and grown by the company in the minds of consumers in using brands, namely loyalty, not loyalty on the basis of anxiety. This can be done by management by managing the entire company order, both human resources, product quality, production processes, services and maintaining a good image with consumers so that the business process becomes a reflexivity to the unity of God.

\section{Positive Image: Avoiding Unfair Competition}

In the concept of branding that is in accordance with Islamic business ethics, Islam has arranged signs for how to deal with business competition in the sharia corridor as the following hadith of Prophet Muhammad PBUH:

"From Abu Hurairah RA, Prophet Muhammad PBUH said: do not envy one another, do not cheat each other, do not hate each other, do not turn back to each other, and do not buy something that will be bought by others, and become servants of God, a Muslims are brothers to other Muslims, they should not subordinate him, be indifferent to him, lie to him and vilify him, fear that here while pointing to His chest three times - enough is said to be evil if he insults his fellow Muslims, forbidden to a Muslim from another Muslim, his blood, his wealth and pride "(HR. Muslim).

According to Muhammad bin Ismail bin Shalah bin Muhammad alHusainy in his book Subul al-Salam as quoted by Arifin (2018), this hadith explains several things which are prohibited by Allah SWT; At-Tahasud (Mutual support); Al-Munajashah (cheating each other); At-Tabawudl (hate each other); At-Tadabur (back to back); and the prohibition of committing tyranny.

\section{Islamic Products: Products Must Be Halal and Good}

The halalness of a product has detailed specifications. Imam Al-Ghazali in Sucipto (2012) suggests halal and illicit perspectives are classified into two types, namely haram because the essence of the goods themselves, second because of the nature of the goods (process or characteristic) itself. The first aspect is halal according to the essence, or from the product itself. One of the 
Jurnal Ekonomi dan Perbankan Syariah

Vol. 7. No.1, April 2019: 53-67, ISSN (cet): 2355-1755 | ISSN (online): 2579-

6437

\section{| 57}

verses that explain the element of illicit products according to the essence of the Qur'an is:

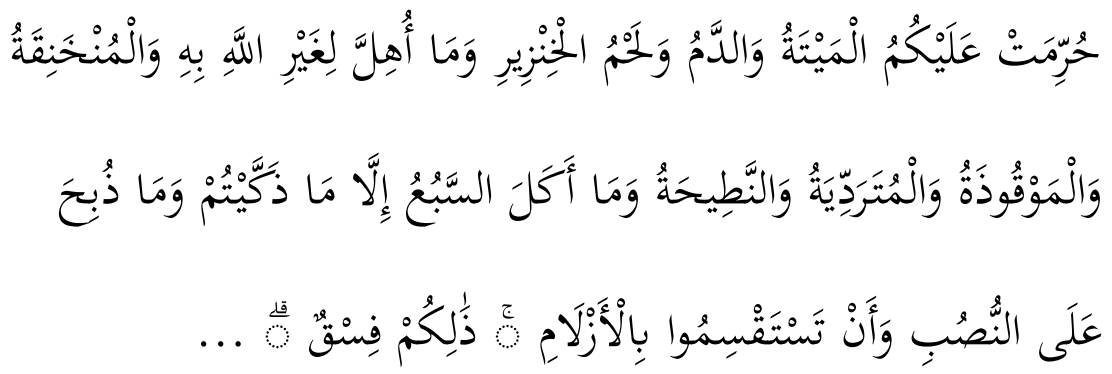

Prohibited to you are dead animals, blood, the flesh of swine, and that which has been dedicated to other than Allah, and [those animals] killed by strangling or by a violent blow or by a head-long fall or by the goring of horns, and those from which a wild animal has eaten, except what you [are able to] slaughter [before its death], and those which are sacrificed on stone altars, and [prohibited is] that you seek decision through divining arrows. That is grave disobedience. (Q.S Al Maidah [5]: 3)

The interpretation of this verse relates to objects that are forbidden by Allah, objects that are forbidden by Allah in this verse are due to the evil in them and also will cause evil on certain sides of human life (Qutb, 2002).

In addition, the process of making products must also be in accordance with the Shari'a, as in meat food products, the process of slaughtering animals for meat extraction must be in accordance with Islamic law. Besides that the maslahat aspects must also be maintained by observing the five main elements of Maqasid al-Shari'ah (the purpose of Islamic law): safeguarding religion, soul, mind, lineage, and wealth. In terms of products that have use and benefit values according to Islam, they can be applied as follows (Syahbuddin and Syukur, 2017):

a) Products made must have clear benefit goals

b) The product does not contain things that endanger the lives of consumers, this is a reflection of the application of hifdzu an-nafs (guarding the soul).

c) Products that are made are not for means of disobedience or leading to immorality.

d) Products are made not as a means to exploit human greed.

\section{Islamic Products: Product Quality Must Be Guaranteed}

Product quality is one of the market's main strengths. Product quality has a direct impact on the performance of a product or service, therefore quality is closely related to customer value. 
58 | Lina Herlina, M.Luthfi Hamidi, Muhammad Doddy: The Concept of Branding in Islamic Business Ethics Perspetive

In line with this, according to Prawirosentono (2002), prime quality products will indeed be more valuable to consumers and eventually can increase sales volume. But more than that quality products have other important aspects, namely:

a) Consumers who buy products based on quality generally have a large product loyalty compared to consumers who buy based on price orientation.

b) Contradictory to traditional business thinking, it turns out that producing quality goods does not automatically cost more by producing low-quality products.

c) Selling quality goods, the possibility of receiving complaints and returns from consumers.

From this point it can be concluded that in building a brand that is in accordance with Islamic business ethics must pay attention to the product itself, which must be halal, masamat and guarantee product quality as a reflexivity of the principle of balance (equilibrium) from the principles of Islamic business ethics.

\section{Fair Prices: Reasonable Profit Taking}

Talking about prices in Islam through various sharia opinions and the opinions of the ulama are not very detailed related to pricing strategies. In general, pricing in Islam is left to market mechanics, this refers to the hadith of the Prophet Muhammad PBUH through Anas Bin Malik RA:

"Sometime in the time of Rasulullah PBUH the price crawled up. Then people say, "O Messenger of Allah, set prices for us". The Messenger of Allah said, "Verily Allah is the one who sets the price, which narrows and smoothes rizki, and truly I hope to meet God in the condition that no one of you demands me with a tyranny, whether in blood or wealth," (HR Tirmidzi and Abu Daud).

Islam prohibits the taking of profits that contain elements of gharar in them and orders the taking of reasonable profits. An-Nabhani (2009) says that ghabn is selling an item or service at a price higher or lower than the average market price. Ghabn fahisy is to set a price that makes no sense because it is too high or too low without the consumer knowing it (p. 203). Ghabn Fahisy is prohibited in Islam because it contains elements of fraud in prices that can cause harm to others.

From this point it can be concluded that not always the concept of building a brand by setting a high price will produce a good brand image for consumers, especially if it is not comparable to the quality of the product provided. On the contrary, if setting prices and taking profits is too high, it might make consumers look for other products that are priced accordingly.

\section{Fair Prices: Keep away from Fair Price Competition}

In modern economic practices often encountered political practices of dumping (selling goods below market prices) or in fiqih muamalah is called siyasyah ighraq, this practice is not only in the scope of ordinary trade, sometimes also occurs in international trade. 
Jurnal Ekonomi dan Perbankan Syariah

Vol. 7. No.1, April 2019: 53-67, ISSN (cet): 2355-1755 | ISSN (online): 25796437

$\mathbf{5 9}$

Regarding this price war, Prophet Muhammad PBUH said through the history of Abdullah bin Umar:

"Do not sell, compete with the sale of your brother" (H.R. Bukhari).

Umar bin Khattab once expelled the seller who carried out the practice of dumping on the market as narrated by Imam Malik and al-Baihaqi: From Sa'id bin al-Musayyab that Umar bin Khattab had passed Hâtib bin Abû Balta'ah who was selling raisins in the market then Umar bin Khattab said to him; "There are two choices for you, raising prices or leaving your market" (Anggraeni, 2015).

From this point it can be concluded that Islam does not regulate in detail the limits of pricing, meaning business people may set prices freely but must be within the limits of feasibility. And may not conduct a price war with the intention of bringing down a competitor, but compete in a fair price, by showing excellence in quality and service provided as the application of the principle of free will in the principles of Islamic business ethics.

\section{Islamic Brands: Avoiding trademark disputes}

Referring to Huda and Jannah (2012) a trademark is an identity in the form of a name or symbol (both in the form of a logo, stamp / packaging) that is distinguishing between goods and services from a particular company (p. 1). Therefore, the trade erect can be an intangible asset because it can be intellectual capital that has high economic value. Brands are very close to business image, goodwill and reputation.

The following is the legal basis for the protection of trademark rights, as in the Qur'an:

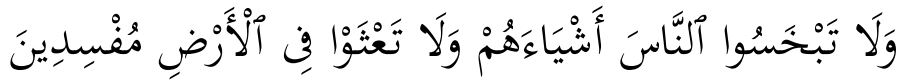

"And do not deprive people of their due and do not commit abuse on earth, spreading corruption.” (QS. Asy- Syu'ara' [26]: 183).

In the business world there are many cases of brand disputes, whether intentionally imitating the logos or brand names of other parties, or those that happen to resemble. Therefore, registration of patents or trademarks is very necessary to obtain legal protection. All forms of legislation related to Intellectual Property Rights (IPR) have been included in the Copyright Act number 28 of 2014.

At this point it can be concluded that in building a brand based on Islamic ethics, it should respect the trademarks of other parties, not only to get a good brand image in the minds of consumers, eventually taking or imitating other brands in terms of brand names, logos and packaging. 
60 | Lina Herlina, M.Luthfi Hamidi, Muhammad Doddy: The Concept of Branding in Islamic Business Ethics Perspetive

\section{Islamic Brands: Halal Labels Must Be Guaranteed}

Labeling is closely related to packaging. Labels are part of a product that conveys information about products and sellers. A label can be part of a package, or it can also be an identification that is listed on the product (Tjiptono, 2008).

But in reality, the halal label does not always guarantee the halal of the product in the package. Referring to Nuryati (2008) Misuse of halal labels is also often carried out by fraudulent producers.

The legal basis for the entry into force of halal certification is in QS. An-Nahl: 114 as follows:

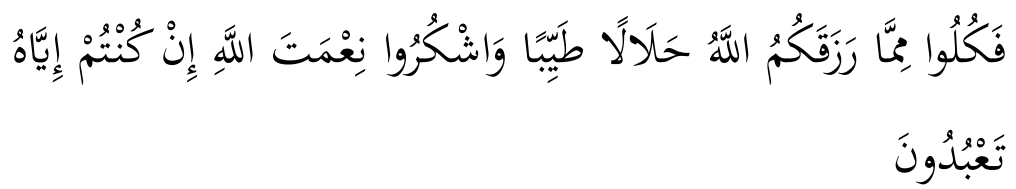

"Then eat of what Allah has provided for you [which is] lawful and good. And be grateful for the favor of Allah, if it is [indeed] Him that you worship." (QS. An-Nahl [16]: 114)

Based on the 2003 Ministry of Religion Halal Certificate guidelines, halal products have criteria:

a) Does not contain pork and food ingredients derived from pigs.

b) Does not contain prohibited ingredients, such as ingredients from human organs, blood, dirt, and so on.

c) All materials originating from halal and slaughtered through Islamic law.

d) All foods and drinks that do not contain bread (Nuryati, 2008).

From this point it can be concluded that the company must be honest in labeling the packaging. Especially the inclusion of halal labels in a product must be absolutely guaranteed because building a brand in Islamic business ethics has principles of purpose, justice and responsibility. The principle of justice and responsibility is its dimensions not only to consumers but also to the creator.

\section{Islamic Promotion: Use of an Endorsement According to Ethics}

Endorsement according to Islam is a marketing communication strategy by using well-known figures such as artists, fashion bloggers, stylish fashion and others as supporting tools and supporting public interest in the products offered on social media used, in ways and processes that are in accordance with sharia provisions (Arifin, 2018).

Islamic scholars have explained some ethics endorsers in marketing products, including Imam al-Ghazali in the book Ihya Ulumuddin as follows:

1) Endorsers have to fit into the sharia and not be dressed sexy.

In the business world, most companies still consider beautiful female models to have a special appeal for consumers, especially models with sexy clothes. Even 
Jurnal Ekonomi dan Perbankan Syariah

Vol. 7. No.1, April 2019: 53-67, ISSN (cet): 2355-1755 | ISSN (online): 2579-

6437

| 61

though in the Islamic business, ethics and the boundaries of the sharia are clear that must be adhered to by the advertising model in marketing their products.

2) Do not praise products that are promoted excessively

Imam al-Ghazali explained that an advertising star is recommended not to praise products that are promoted by criteria that are not actually present in the product, because it is a lie to consumers.

3) Do not use the oath in the name of God

A spokesperson should not use the oath in the name of Allah in promoting a product. If he lies on the oath, he has committed a perjury which is one of the major sins.

4) Transparent in promoting a product

A spokesperson must be transparent in promoting the product advertised by explaining the shortcomings of the product being promoted, both non-visible and visible. And not allowed to cover up the shortcomings, because it is a form of lies and fraud.

5) There is no content that vilifies other products.

One of the ethics advocated by the Quran and Hadith is to stay away from the Koran. What is meant by tahqir here is to disparage or denounce the other party or the product.

From this point it can be concluded to build a brand in terms of promotion, the use of advertising stars must be in accordance with the boundaries of Islamic ethics. Because business goals in Islam are not just seeking profit but also blessing. Even though advertising stars are considered capable of attracting consumer interest, the things that advertising stars must highlight to attract consumers are not their body beauty, but the reputation and quality of products delivered with honesty.

\section{Islamic Promotion: Use of a Reliable Slogan}

The slogan is very important in branding as a campaign management activity. Therefore, when a company will give a label in the form of a slogan on a company's product or service, then the company has made a contract in the form of a commitment with the customer at that time as well as the ethical and moral management of the company at stake (Chairiawaty, 2012).

The term or context of communicating in the Koran is found in the qaulan lafazh (words). Referring to Chairiawaty (2012), there are several qaulan terms which guide the delivery of the following message:

\section{Qaulan sadidan (Honest Words)}

In this case the slogan must inform or convey truth, factual, honest, also not manipulate or manipulate facts (Chairiawaty, 2012). 
62 | Lina Herlina, M.Luthfi Hamidi, Muhammad Doddy: The Concept of Branding in Islamic Business Ethics Perspetive

\section{Qaulan baligho (Impressive Words)}

The word baligh means precise, straightforward, eloquent, and clear meaning. So that communication is right on target, the style of speech and the message conveyed in the slogan should be with a sentence that impresses the heart of the community.

3. Qaulan karieman (Gentle words)

Qaulan kariman is a noble word, coupled with respect and glorification, pleasant to hear, gentle, and manners (Chairiawaty, 2012). In the slogan, those who will read the company's slogan are all people, so it's best to use sentences that are soft and not sarcastic about other products.

4. Qaulan layyinan (Smooth and polite words)

Qaulan layyinan means soft talk, with a sound that is pleasant to hear, and full of hospitality, so that it can touch the heart. Layyinan is a sarcastic word, not with straightforward or straightforward words, especially rude (Chairiawaty, 2012). In this slogan it can be used as a figurative sentence that refers to company commitment.

\section{Qaulan ma'rufa (Good Words)}

Qaulan mMa'rufa also means useful talks and raises good (maslahat). Qaulan Ma'rufa is softening words and keeping promises. The slogan is not just an anesthetizing sentence to attract consumers, but a promise that must be kept. 6. Qaulan Maysura (Easy to Understand)

Qaulan Maysura means easy speech, which is easy to digest, easy to understand, and understood by the communicant. Other meanings are words that are pleasant or contain joyful things.

From this point it can be concluded that the slogan as one of the tools to communicate the brand is indeed considered quite effective in giving the product and company positioning to the community. Thus, Islam has given clear limits to every business person in making a slogan, which is interpreted as a company commitment to customers that is in line with the principle of benevolence to achieve customer loyalty.

\section{METHODOLOGY}

This research is qualitative research. The research used is descriptive qualitative research. Descriptive qualitative research is in the form of research with a method or approach to a case study). This research focuses intensively on one particular object that studies it as a case. Case study data can be obtained from all parties concerned, in other words in this study collected from various sources (Bungin, 2003).

Case studies will be carried out on three brands including Muslim clothing manufacturer Rabbani, Wardah cosmetics manufacturer and sharia hotel brand under the brand name Hotel Sofyan. 


\section{DISCUSSION: CASE STUDY}

The following is an example of a company that has done good branding, thus affecting people's perceptions of the company's image:

\section{RABBANI}

Rabbani is a garment company engaged in the retail of Muslim fashion with the tagline Professor of Kerudung Indonesia. Rabbani is one of the first and largest instant veil companies in Indonesia by releasing a flagship product in the form of instant veils and other products that have also been developed namely Muslim clothing including kemko, tunic, kastun, and other equipment such as ciput / inner veils and accessories.

The origin of the word Rabbani is inspired by one of the surah in the Quran, namely Ali Imron verse 79 which means that the servants of Allah are willing to teach and be taught Quran.

The image of Rabbani products is known by the public. Rabbani has branches spread in the country and abroad. This is because Rabbani is a manufacturer of hoods that have been established for a long time and always create quality products that are tailored to the times and the desires and needs of the community. In addition, Rabani's noble vision and mission strongly reflects the management of Islamic business which always upholds Islamic values, so that the loyalty of Rabbani consumers is a wala wal-bara 'loyalty that is based on the reflexivity of love for Allah.

Therefore, the impact of the good Rabbani brand image of the community always believes that the product launched by Rabbani will be in accordance with consumer expectations. The expectations of consumers who have successfully achieved will be possible to continue to consumer loyalty.

\section{WARDAH}

Wardah Cosmetic is a well-known cosmetic brand with the tagline of the halal wardah from the start, one of the original Indonesian cosmetics that is specifically for Muslim women and generally for all women who want to use cosmetics that are safe and do not contain dangerous ingredients and are certified halal with the slogan " Inspiring Beauty". Some of the advantages of Wardah Cosmetic:

1) Wardah Cosmetic is committed for decades to always prioritize quality in supporting women to look beautiful according to their respective characters.

2) Every creation of Wardah cosmetics and skin care is the result of a modern technology process under the supervision of experts and dermatologists.

3) Wardah products contain safe and halal raw materials, created for the comfort and tranquility of women who use them. 
64 | Lina Herlina, M.Luthfi Hamidi, Muhammad Doddy: The Concept of Branding in Islamic Business Ethics Perspetive

4) Before product launching, Wardah had to make a blind test so that the products produced were truly quality and safe. Because consumer safety is a top priority and one element that Wardah Products cannot contend with.

From the explanation related to the Wardah company, it can be concluded that Wardah's branding is from the quality of halal products that are truly considered, because Wardah wants to be known as a halal cosmetic icon for Muslim women. In addition, in terms of endorsement Wardah is also very concerned about ethics to maintain its image as halal cosmetics for Muslim women, so that it is proven that to date Wardah consumer loyalty is increasing.

Halal cosmetics are increasingly in demand by the people of Indonesia. Observers consider today's trends show the public likes something distinctive and certain to be halal. The momentum was utilized well by Wardah Cosmetics, one of the halal cosmetics manufacturers in Indonesia. Wardah Cosmetics recorded high growth. Wardah Cosmetics has a turnover of 75 percent per year for the past four years. Yet according to the AC Nielsen survey, the development of cosmetic turnover per year is only 15 percent per year. Wardah admitted that his growth reached 80 per year. Wardah Brand and Product Development Coordinator Alif Kartika said Wardah had experienced significant growth in the past 5 years. According to him, Wardah's growth was driven by quality which prioritized halal by using natural and safe ingredients. Wardah is also active in promoting (Republika, 2013).

In addition, in the 2018 Indonesia Halal Expo (INDHEX) event Wardah won victory as the Halal Top Brand in the category of Cosmetics and the Best Halal Advertisements of all halal labeled products in Indonesia (Top Brand Award, 2017).

\section{HOTEL SOFYAN}

Sofyan Hotel is the first hotel in Indonesia that carries the concept of sharia. Sofyan Hotel deserves to be the choice of Muslim tourists who crave maximum comfort, but still want to maintain syari principles during their stay. Sofyan Hotel has a restaurant that serves halal food that has been certified by MUI. For bars, for example, only mix herbal and non-alcoholic drinks. At this hotel there are also fitness center fitness facilities. Besides that, in each room there are also prayer mats and holy Qur'an.

Changes to the hotel concept actually brought luck to Sofyan Hotels. After the night club facilities were closed, the sale of hotel rooms actually rose to reach 20 percent and the occupancy rate exceeded 70 percent. The success made PT Sofyan Hotels Tbk appointed as a strategic partner of the Ministry of Tourism in developing sharia hotels in Indonesia and among member countries of the Organization of Islamic Cooperation (OIC).

The quality of the various facilities and services of Sofyan Hotel has been recognized by many parties. No wonder the hotel was successful in winning a series of tourism awards at national and even global levels. In 2015, for example, one of the hotels belonging to the Sofyan Hotels network, Sofyan Hotel Betawi was crowned the World's Best Family Friendly Hotel in the 2015 international 
Jurnal Ekonomi dan Perbankan Syariah

Vol. 7. No.1, April 2019: 53-67, ISSN (cet): 2355-1755 | ISSN (online): 25796437

| 65

prestigious World Halal Travel Award. Sofyan Hotels' track records managed sharia hotels over the past two decades and even spread to Malaysia, Japan, and South Korea.

Following the trends and developments of halal lifestyle, Sofyan Hotel compared its products as the first hotel to carry the sharia concept. Of course, hotel sofyan must continue to improve the service of the halal concept, it must be more selective in accepting guests and not accepting non-Muslim guests in one hotel room, as well as food and beverages served to be free from things that are forbidden by Islamic law. Also, the facilities and infrastructure of worship must be more comfortable so that this sharia hotel becomes a classy and competitive hotel.

\section{CONCLUSION}

From the explanation in the previous sections, it can be concluded that the concept of branding in the perspective of Islamic business ethics is as follows branding has an important role in business as a differentiator, as promotion and attraction, as an image builder, giving confidence, guaranteeing quality, prestige and as a market controller. Branding in accordance with Islamic ethics rules has a positive effect on increasing customer loyalty and growing business turnover.

Islam has set ethics in branding as signs to fit the boundaries of the Shari'a such as in terms of Islamic imagery by building loyalty of al-wala 'wal bara' and avoiding unfair competition. In terms of Islamic products, namely by ensuring that the product must be halal and maslahat also the quality of the product must be guaranteed. In terms of the concept of a fair price, namely by taking reasonable profits and avoiding unnatural price competition. In terms of the Islamic brand that is by distancing from imitating the other party's trademark and making sure there is a guarantee of the halal label. And the last is in terms of Islamic promotion by using ethics spokespersons and using reliable slogans.

Application of examples of branding that are in line with Islamic business ethics in Indonesia include the Rabbani brand which highlights the high-class quality, Wardah with its halal brand and Sofyan Hotel which carries the concept of the sharia hotel. From these cases it can be concluded that a brand that is in accordance with Islamic law has proven to have a good image in the community so that it fosters customer loyalty. 
66 | Lina Herlina, M.Luthfi Hamidi, Muhammad Doddy: The Concept of Branding in Islamic Business Ethics Perspetive

\section{BIBLIOGRAPHY}

An-Nabhani, T. (2009). Membangun Sistem Ekonomi Alternatif Persfektif Islam. Surabaya: Risalah Gusti.

Anggraeni, N. (2015). Dumping Dalam Perspektif Hukum Dagang Intenasional dan Hukum Islam. MAZAHIB Jurnal Pemikiran Eknomi Islam, X1V, 159167.

Bungin, Burhan. (2003). Analisis Data Penelitian Kualitatif. Jakarta: RajaGrafindo Persada

Chairiawaty. (2012). Branding Identity: Sebuah Tinjauan Mengenai Etika Bisnis Islam. Jurnal Ilmu Komunikasi, Vol.2, No.2, Oktober 2012 ISSN: 2085-981X, 2(2).

Dewi, Ike Janita, Ranus, Fransiskus dan Wasiyati, K. (2005). Inspirasi Bisnis : Perspektif Baru Dala Strategi Branding, Bisnis dan Karir. (I. J. Dewi, Ed.) (1st ed.). Jakarta: Amara Books.

Fauzan, S. bin F. bin A. Al. (1998). Kitab Tauhid. Jakarta: Akafa Press.

Haryanti, F. (2017). Berbentuk Mirip Penis Roti di Taiwan Ramai Diserbu Pengunjung. $\quad$ Retrieved from https://m.liputan6.com/amp/3018618/berbentuk-mirip-penis-roti-ditaiwan-ramai-diserbu-pengunjung

Hendrawan, A. (2014). Pola Dasar Penggunaan Brand Dari masa ke Masa. Jurnal Fakultas Desain, 1, 22-28.

Huda, N., \& Jannah, M. (2012). Perlindungan Hak Merek Dagang Menurut Hukum Islam. SUHUF, 24, 1-13.

Karim, A. (2004). Sejarah Pemikiran Ekonomi Islam. Jakarta: Grafindo.

Kotler, Philip dan Amstrong, G. (1997). Dasar-dasar Pemasaran (1st ed.). Jakarta: PT Prenhalindo.

Nika. Sengketa gugatan karena logo mirip (2014). Retrieved from http://m.merdeka.com/amp/uang/4-sengketa-gugutan-karena-logo-mirip/

Nuryati, S. (2008). Halalkah Makanan Anda? Solo: PT Aqwam Media Profetika.

Oktaviani, F. et al. (2018). Penguatan Produk UMKM “Calief” Melalui Strategi Branding Komunikasi. Jurnal Abdimas BSI, 1, 348-354.

Prawirosentono, S. (2002). Filosofi Baru Tentang Manajemen Mutu Terpadu Total Quality Management Abad 21 Studi Kasus dan Analisis. Jakarta: Bumi Aksara.

Profil Wardah. (2010). Retrieved February 13, 2019, from https://www.google.com/url?sa=t\&source=web\&rct=j\&url=https://www. paragon-innovation.com

Quthb, S. (2002). Tafsir Fi Zhilalil Qur'an Jilid 3. (H. Kurniawan, Ed.) (1st ed.). 
Jurnal Ekonomi dan Perbankan Syariah

Vol. 7. No.l, April 2019: 53-67, ISSN (cet): 2355-1755 | ISSN (online): 2579-

6437

| 67

Jakarta: Gema Insani Press.

Randi. Teguran Tertulis Program Siaran Iklan "Shimizu" RCTI (2016).

Retrieved from http://www.kpi.go.id/index.php/id/lihat-sanksi/30746teguran-tertulis-program-siaran-iklan-shimizu-rcti/

Sofyan Hotel Tbk. (2016). Retrieved February 13, 2019, from https://www.google.com/url?sa=t\&source=web\&rct=j\&url=http://sofyan hotel.co.id

Sucipto. (2012). Halal dan Haram Menurut Al-Ghazali dalam Kitab Mau'idotul Mukminin. Jurnal Asas, 1, 116-127.

Syahbuddin, Fahmi dan Syukur, F. A. (2017). Konsep Marketing Mix Syariah. Jurnal Ekonomi Dan Perbankan Syariah 72, 5(1), 71-94.

Syamsul Arifin, M. (2018). Endorsment Dalam Perspektif Islam. Universitas Islam Negeri Sunan Ampel.

Tjiptono, F. (2008). Strategi Pemasaran. Yogyakarta: ANDI.

Tjiptono, F. (2014). Branding \& Brand Longevity. Yogyakarta: C.V Andi Opset.

Top Brand Award 2017. (2017). Jakarta. Retrieved from http://www.topbrandaward.com/top-brand-survey/survey-result/top_brand_index_2017_fase2

Yusanto, M. I., dan Widjajakusuma, M. K. (2002). Menggagas Bisnis Islami. Jakarta: Gema Insani Press.

Yusof, M., Dan, \& Jusoh, W. (2014). Islamic Branding: The Understanding and Perception. Procedia - Social and Behavioral Sciences, 130, 179-185. https://doi.org/10.1016/j.sbspro.2014.04.022

Zuraya, N. (2013). Kosmetik Halal Semakin Diminati. Jakarta. Retrieved from https://www.republika.co.id/berita/ekonomi/ritel/13/10/30/mvgy81kosmetik-halal-semakin-diminati/ 